\title{
MODEL PEMBELAJARAN PENDIDIKAN AGAMA ISLAM INTEGRATIF
}

\author{
Ida Farida Isnaeni \\ Teacher of SMP N 1 Purwokerto Kab. Banyumas, Jawa Tengah \\ Email: mulkeismatondang@yahoo.co.id
}

\begin{abstract}
National education aims at realizing the Indonesian people who is faithful and devoted. Achievement of these objectives need to be supported by the pattern of implementation of learning in integrative educational institutions. The integrated learning model is the model of lerning to combine several subsubjects with another sub-subjects in a subject; or even between subjects. Expansion of the responsibility of coaching faith and taqwa who had been on religious teachers, and now should be for all teachers and other school components. This responsibility does not mean that the non-religion teachers teach faith and taqwa in the subject of their teaching, but they should support their learning to the value of that values, next to the substance of their subjects. This step is based on the principle that every subject must contain three elements integratedly, they are their subject of teaching, scientific and value. So, the teaching must have values that support the learning of characters (character / moral).
\end{abstract}

Keyword: Education, Integrated Islam, faith and Taqwa

\begin{abstract}
Abstrak
Pendidikan nasional bertujuan mewujudkan manusia Indonesia yang beriman dan bertaqwa. Pencapaian tujuan tersebut perlu disokong oleh pola pelaksanaan pembelajaran di lembaga pendidikan yang integratif. Model pembelajaran integratif atau terpadu yaitu model pembelajaran yang mencoba memadukan beberapa pokok bahasan dengan pokok bahasan lain dalam satu mata pelajaran. Selain itu bisa juga antar mata pelajaran. Perluasan tanggung jawab pembinaan keimanan dan ketakwaan yang selama ini berada di pundak guru agama, kini harus menjadi tugas semua guru dan komponen sekolah lainnya. Tanggung jawab ini bukan berarti bahwa guru-guru lain mengajarkan keimanan dan ketakwaan dalam format mata ajar, namun para guru di luar mata ajar agama harus mendukung terciptanya pembelajaran yang menjadikan nilai keimanan dan ketakwaan sebagai salah satu komponen, di samping bidang substansi mata ajar dan kedalaman bidang keilmuan. Langkah ini dilakukan berdasarkan prinsip bahwa dalam setiap mata ajar harus memuat tiga unsur secara terpadu, yaitu substansi mata ajar yang bersangkutan, keilmuan dan nilai (value). Dalam kerangka inilah setiap mata ajar harus memiliki nilai-nilai yang mendukung pembelajaran karakter (akhlak/moral).
\end{abstract}

Kata Kunci: Pendidikan, Islam Integratif, Iman dan Taqwa 


\section{PENDAHULUAN}

Pendidikan nasional berfungsi mengembangkan kemampuan dan membentuk watak serta peradaban bangsa yang bermartabat dalam rangka mencerdaskan kehidupan bangsa, bertujuan untuk berkembangnya potensi peserta didik agar menjadi manusia yang beriman dan bertaqwa kepada Tuhan Yang Maha Esa, berakhlak mulia, sehat, berilmu, cakap, kreatif, mandiri, dan menjadi warga negara yang demokratis serta bertanggung jawab. ${ }^{1}$

Jika mengacu pada fungsi dan tujuan pendidikan nasional tersebut jelas sekali bahwa peran nilai-nilai agama menjadi sangat penting dalam setiap proses pendidikan yang terjadi di sekolah. Karena terbentuknya manusia yang beriman dan bertaqwa serta berakhlak mulia tidak mungkin terbentuk tanpa peran dari agama. $^{2}$

Peningkatan keimanan dan ketaqwaan siswa sesuai dengan tujuan pendidikan nasional tersebut bisa dilakukan melalui mata pelajaran, kegiatan ekstra kurikuler, penciptaan situasi yang kondusif maupun kerjasama sekolah dengan orang tua dan masyarakat.

Peningkatan iman dan taqwa melalui mata pelajaran dilakukan oleh guru yaitu dengan cara mengkaitkan nilai-nilai Imtaq dan Iptek dalam pembelajaran tanpa mengubah kurikulum yang sudah ada.

Keberhasilan siswa dalam belajar yang dapat meningkatkan Imtaq sangat dipengaruhi oleh kondisi internal siswa maupun faktor eksternal siswa. Salah satu faktor eksternal yang ikut berpengaruh atas keberhasilan siswa dalam memahami suatu topik pembelajaran yang berasal dari guru adalah kemampuan guru dalam memilih metode dan pendekatan pembelajaran yang tepat sehingga nilai-nilai Imtaq bisa mewarnai dalam pembelajaran tersebut.

Dalam suatu proses pembelajaran tidak ada suatu pendekatan pembelajaran yang tepat untuk semua topik dan semua situasi, oleh karena itu guru dalam menentukan metode dan pendekatan pembelajaran apa yang harus dipilih harus senantiasa memperhatikan kondisi siswa, sarana prasarana yang ada maupun metode pembelajaran apa yang akan dibahas.

Begitu juga di setiap sekolah tidak semua siswa mempunyai latar belakang sosial budaya, ekonomi, agama serta motivasi yang sama dalam setiap belajarnya, kondisi ini mengharuskan setiap guru memahami karakteristik dari siswa atau kelas yang dihadapi jika ingin proses pembelajarannya bisa berhasil.

1 Undang-Undang Sistem Pendidikan Nasional Nomor 20 tahun 2002, Bab II, Pasal 3, (Bandung : Focus Media, 2003), hal. 53

${ }^{2}$ Rosman Yunus dkk, Suplemen Biologi Untuk Peningkatan IMTAQ Siswa SLTA,2003 Depdiknas Dikdasmen Bag. Pro Peningkatan Wawasan Keagamaan, (Jakarta : Depdiknas, 2003), hal. 32 
Kondisi yang berbeda-beda tentang latar belakang kemampuan ekonomi, sosial budaya, agama dan motivasi siswa tersebut dalam belajar, bisa terlihat dari prestasi belajar yang dicapai, akhlak, budi pekerti dan perilaku siswa yang ditunjukkan oleh siswa-siswa dalam kehidupannya sehari-hari

Permasalahan yang muncul adalah: Bagaimana integrasi materi pelajaran dan nilai-nilai agama Islam dalam pembelajaran? Dan Pendekatan pembelajaran apa yang kiranya sesuai dengan materi pelajaran? Serta nilai-nilai Imtaq apa saja yang bisa dikembangkan dalam pembelajaran tersebut? Itulah beberapa persoalan yang akan ditelaah dalam makalah ini.

Salah satu komponen yang secara langsung berkaitan dengan proses belajar mengajar di sekolah adalah keterpaduan materi. Masalah inilah yang akan diangkat dan dikembangkan dalam tulisan ini. Keterpaduan materi yang dimaksud di sini adalah keterpaduan antara materi pendidikan agama Islam dengan materi pelajaran lain, seperti Biologi, Fisika, Kimia, Matematika dan sebagainya. Perlu diketahui bahwa dalam pendidikan agama Islam terdapat banyak sekali materi yang memerlukan penjelasanpenjelasan yang rasional, luas dan mendalam. Untuk itulah maka sebagai guru agama Islam dituntut memperluas wawasan pengetahuan lain selain materi pendidikan agama Islam. Masalahnya adalah mampukah para pendidik terutama guru pendidikan agama Islam mengaitkan materi pendidikan agama Islam dengan mata pelajaran lain, dan guru mata pelajaran lain (yang beragama Islam) mengaitkannya dengan pendidikan agama Islam?

\section{PEMBAHASAN}

1. Kurikulum PAI Yang Integratif

Integrasi adalah perpaduan menjadi satu kesatuan yang utuh antara dua pokok bahasan. Jadi yang disebut dengan kurikulum Pendidikan Agama Islam integratif adalah upaya perpaduan antara ilmu agama dan ilmu umum. Hal ini sesuai dengan Jaring Laba-laba Keilmuan yang ditawarkan oleh M. Amin Abdullah :

Kurikulum sebagai salah satu komponen pendidikan perlu dikembangkan secara simultan dalam rangka merespon tantangan di masa depan, menawarkan salah satu bentuknya dengan mengayomi keberagaman anak dalam pembelajaran, yaitu kurikulum integrasi. Dalam bentuk ini, kurikulum terintegrasikan (tidak terpisah-pisah atau terpadu) antara satu metode dengan mata pelajaran lainnya sehingga peserta didik secara signifikan dapat meningkatkan pembelajarannya untuk kehidupan yang sangat penting di dalam masyarakat. ${ }^{3}$

Pendidikan nasional secara umum dan pendidikan agama (Islam) secara khusus dinilai "gagal" dalam menanamkan akhlak kepada peserta didik sehingga

\footnotetext{
${ }^{3}$ John Wiles \& Joseph Bondi, Curriculum Development, (Jakarta : Raja Grafindo 2007), hal : 187-188
} 
mengakibatkan rendahnya kualitas akhlak atau moral peserta didik. Banyak penyebab mengapa pendidikan agama (Islam) berjalan belum maksimal dalam penanaman akhlak, diantaranya, bahwa PAI di sekolah terlalu verbalistik dan formalistik, metodeloginya yang monoton dan statis, pendekatannya yang terlalu normatif dan sistem evaluasi yang terlalu memprioritaskan kepada penilaian kognitif. ${ }^{4}$ Sementara lain bahwa PAI hanya fokus terhadap pertumbuhan kesadaran nilai-nilai ajaran agama (kognitif) dan mengabaikan kemauan dan tekad untuk mengamalkan nilai-nilai ajaran agama (afektif dan konatif-volutif). ${ }^{5}$

Lebih lanjut Al-Faruqi menerangkan bahwa Islamisasi ilmu pengetahuan dapat dicapai melalui pemanduan ilmu-ilmu baru ke dalam khazanah warisan Islam dengan membuang, menata, mengalisa, menafsir ulang dan menyesuaikannya menurut nilai pandangan Islam.

Sementara dari sudut metodologi, Al-Faruqi mengemukakan ide Islamisasi ilmunya bersandarkan Tauhid. Dalam pandangan Al-Faruqi, metodologi tradisional tidak mampu memikul tugas ini karena beberapa kelemahan. Pertama, ia telah menyempitkan konsep utama seperti fiqh, faqih, ijtihad dan mujtahid. Kedua, kaedah tradisional ini memisahkan wahyu dan akal, dan seterusnya memisahkan pemikiran dan tindakan. Ketiga, kaedah ini membuka ruang untuk dualism sekuler dan agama.

Pendidikan sebagai suatu proses mempengaruhi peserta didik agar dapat menyesuaikan diri sebaik mungkin terhadap lingkungannya sehingga menimbulkan perubahan dalam dirinya yang memungkinkan untuk berfungsi secara dekat dalam kehidupan masyarakat. Nata menyatakan bahwa perubahan dan perkembangan zaman yang begitu cepat yang terjadi di masyarakat (era global) seyogyanya berdampak juga terhadap perubahan paradigma pendidikan salah satunya paradigma kurikulum. ${ }^{6}$ Kurikulum menjadi bagian terpenting dalam proses pembelajaran guna mencapai tujuan pendidikan, karena kurikulum dijadikan sebagai acuan dalam pembelajaran pada setiap lembaga pendidikan yang disesuaikan dengan kemampuan peserta didik, tanpa terkecuali keberhasilan PAI harus disertai dengan penyusunan dan pengembangan kurikulum yang tepat, yaitu dengan menetapkan landasan yang kuat berdasarkan hasil pemikiran dan penelitian yang mendalam. ${ }^{7}$ Senada dengan hal di atas, Soedjatmoko mengatakan bahwa, "sumber PAI bagus, tetapi program pembelajarannya sangat tidak bagus" 8

Oleh karena itu, diperlukan solusi terhadap kondisi PAI yang berlangsung di sekolah-sekolah umum agar terselenggara dengan efektif dan efisien dengan melakukan

\footnotetext{
${ }^{4}$ Muhaimin, Paradigma Pendidikan Islam, (Jakarta : 2001, hal : 106

${ }^{5}$ Mochtar Buchori, Posisi dan Fungsi PAI dalam Kurikulum Perguruan Tinggi Umum,(Jakarta : 1992)

${ }^{6}$ Abudin Nata, Perspektif Islam Tentang Strategi Pembelajaran, (Jakarta : 2007), hal : 79

${ }^{7}$ Nana Syaodih S., Pengembangan Kurikulum, (Jakarta :2001), hal : 38

${ }^{8}$ Soedjatmoko, Dimensi Manusia Dalam Pembelajaran, (Jakarta : LP3S, 2007), hal : 58
} 
perubahan dan perbaikan pendekatan serta pengembangan kurikulum. Sehingga apa yang dipelajari peserta didik dapat bermanfaat untuk diterapkan dalam kehidupan sehari-hari bukan menjadikannya asing di masyarakat dan merasa dirinya 'tercabut' dari lingkungannya.

\section{Materi PAI Integratif}

Beberapa contoh pembelajaran yang terkait antara mata pelajaran umum dengan ayat-ayat Al-Qur' an yang secara eksplisit dan tersurat bisa dijadikan acuan dalam mengintegrasikan antara Imtak dan Iptek sebagaimana di bawah ini :

\begin{tabular}{|c|c|}
\hline $\begin{array}{c}\text { Mata } \\
\text { Pelajaran }\end{array}$ & Ayat Al-Qur'an \\
\hline PPKn & $\begin{array}{l}\text { QS. Al-Ikhlas tentang Ketuhanan Yang Maha Esa } \\
\text { QS. Ar-Rahman ayat } 9 \text { tentang Keadilan } \\
\text { QS. Al-Isra ayat 132, Al-Hujaraat ayat } 13 \text { tentang persatuan } \\
\text { QS. An-Nisa ayat 59, Ali Imran ayat } 159 \text { tentang Kerakyatan } \\
\text { QS. An-Nisa ayat 127, tentang Keadilan Sosial }\end{array}$ \\
\hline Sejarah & $\begin{array}{l}\text { QS. Al-Hasyr ayat } 18 \text {, Al-Baqarah ayat } 154 \text { tentang peristiwa masa } \\
\text { lalu yang merupakan pelajaran } \\
\text { QS. Huud ayat } 120 \text {, tentang sejarah merupakan pelajaran } \\
\text { QS. Yusuf ayat 11, tentang sejarah merupakan ibarat (pesan-pesan } \\
\text { simbolik) }\end{array}$ \\
\hline Penjas & $\begin{array}{l}\text { Hadis " Ajarilah anak-anakmu berenang, memanah, dan } \\
\text { menunggang kuda " }\end{array}$ \\
\hline Fisika & $\begin{array}{l}\text { QS. Yasiin, ayat 36-40 tentang matahari, bulan, dan planet lain yang } \\
\text { beredar sesuai dengan garis edar. } \\
\text { QS. Ar-Rahman ayat } 33 \text { tentang manusia dan jin dapat menembus } \\
\text { langit dengan bekal ilmu pengetahuan dan teknologi. }\end{array}$ \\
\hline Kimia & $\begin{array}{l}\text { QS. An-Nahl ayat } 67 \text { tentang buah kurma dan anggur dapat dibuat } \\
\text { minuman yang memabukkan dan rezeki yang baik. } \\
\text { QS. An-Nahl ayat } 68 \text { tentang lebah memberikan manfaat yang besar } \\
\text { bagi manusia. }\end{array}$ \\
\hline Biologi & $\begin{array}{l}\text { QS. Al-Mukminuun ayat 12-14 tentang proses kejadian manusia. } \\
\text { QS. Al-Mukminuun ayat 18-22 tentang perkembangan mahluk hidup. }\end{array}$ \\
\hline Ekonomi & $\begin{array}{l}\text { QS. Al-Baqarah ayat } 201 \text { tentang permohonan kebaikan di dunia. } \\
\text { Ayat-ayat tentang zakat dalam Al-Qur'an. } \\
\text { Ayat-ayat Al-Qur'an tentang riba dan jual beli }\end{array}$ \\
\hline Bahasa & QS. Al-Alaq ayat 1-5 tentang membaca \\
\hline
\end{tabular}




\begin{tabular}{|l|l|}
\hline Geografi & $\begin{array}{l}\text { QS. Al-Hijr ayat } 22 \text { tentang kegunaan udara dan angin. } \\
\text { QS. Al-Anbiya ayat } 20 \text { tentang kegunaan air. }\end{array}$ \\
\hline Kesenian & $\begin{array}{l}\text { QS. Al-Kahfi ayat } 7 \text { tentang segala sesuatu sebagai perhiasan } \\
\text { QS. Ali Imran ayat } 14 \text { tentang keindahan }\end{array}$ \\
\hline
\end{tabular}

3. Contoh Aplikasi Model Pembelajaran PAI Integratif

a. Pengintegrasian nilai-nilai agama Islam dalam pembelajaran Biologi pada pokok bahasan Ekologi.

Munculnya ilmu tentang ekologi merupakan hasil kajian dari berbagai fenomena alam sendiri yang teratur (sunatullah). Keteraturan yang ada di alam membuat manusia bisa membuat prediksi-prediksi tentang apa yang akan terjadi berdasarkan pada fakta-fakta yang ada, sehingga manusia bisa membuat antisipasi -antisipasi. Keteraturan alam ini merupakan bukti bahwa alam ini tidak terjadi dengan sendirinya dan tanpa tujuan, tetapi jelas diciptakan oleh Dzat yang Maha Kuasa dengan tujuan dan maksud tertentu, sehingga manusia memungkinkan untuk memahami.

Petunjuk-petunjuk tentang gejala alam yang teratur dan seimbang itu bagi kita dapat mentafakuri ke-Esa-an sang Pencipta, sehingga mampu membimbing nalar manusia bagi peningkatkan keimanan dan Ketaqawaan kepada-Nya.

Alam semesta beserta isinya diserahkan sepenuhnya untuk dipelihara dan dimanfaatkan untuk keperluan hidup manusia secara bijak agar kita bisa melaksanakan amanah Allah dengan sebaik-baiknya.

Pada dasarnya setiap pokok bahasan dalam Ekologi bisa diintegrasikan dengan nilai-nilai agama Islam, untuk menambah keimanan, dan ketaqwaan siswa, terhadap Tuhan Yang Maha Kuasa, sesuai dengan tujuan pendidikan nasional. Sebagai contoh nilai-nilai agama Islam yang bisa diintegrasikan pada pokok bahasan ekologi. Dalam perspektif ekologi, lingkungan hidup mencakup segala sesuatu yang ada disekitar kita yang terdiri dari faktor biotik dan abiotik serta budaya manusia.

Lingkungan abiotik, yang meliputi segala sesuatu yang tidak hidup yang berupa benda mati yang secara tidak langsung terkaait pada keberadaan hidup, seperti air, tanah, cahaya, kelembaban, udara, $\mathrm{pH}$, keadaan tanah tempat mahkluk hidup berada. Realitas menunjukkan bahwa makhluk hidup tidak dapat hidup sendiri-sendiri, ada saling ketergantungan antara makhluk hidup dengan sesamanya maupun dengan lingkungannya. Di samping itu bahwa aktifitas makhluk hidup termasuk manusia ternyata sangat dipengaruhi dan mempengaruhi terhadap lingkungan tempat hidupnya baik 
lingkungan abiotik maupun biotik. Sebagai contoh mengintegrasikan nilai imtaq ke dalam materi lingkungan dalam suatu proses pembelajaran.

Air merupakan komponen utama yang sangat diperlukan oleh makhluk hidup, tanpa air tidak akan ada kehidupan. Air sebagai sumber kehidupan utama bagi kehidupan makhluk hidup, dijelaskan Allah pada alQuran Surat al-Jatsiyah ayat 5, yang artinya:

"Dan pada pergantian malam dan siang dan hujan yang diturunkan Allah dari langit lalu dihidupkannya dengan air hujan itu bumi sesudah matinya; dan pada perkisaran angin terdapat pula tandatanda (kekuasaan Allah) bagi kaum yang berakal. ". QS. al-Jatsiyah (45) : ayat 5

Tanah menjadikan tempat tinggal sebagian besar makhluk hidup, peranan tanah sebagai lingkungan hidup sangat menentukan, Allah berfirman dalam Surat al-Hijr ayat 19 yang artinya:

"Dan kami telah mengham-parkan bumi dan menjadikan padanya gununggunung dan Kami tumbuhkan padanya segala sesuatu menurut ukuran." QS. Al-Hijr (151): ayat 19

Dan juga diterangkan oleh Allah bagaimana fungsi tanah bagi kehidupan seperti yang terdapat dalam firman Allah yang artinya:

"Dan tanah yang baik, tanamantanamannya tumbuh subur dengan seizin Allah; dan tanah yang tidak subur, tanaman-tanamannya hanya tumbuh merana. Demikianlah Kami mengulangi tanda-tanda kebesaran Kami bagi orang-orang yang bersyukur". QS. al-A'Raf (7) : ayat 58

Angin, merupakan udara yang bergerak terjadi karena perbedaan tekanan udara, adanya angin menjadi tanda akan adanya hujan, dimana air hujan menjadi sesuatu yang sangat penting bagi mahkluk hidup, disamping itu angin akan mempengaruhi kehidupan terutama untuk tumbuh-tumbuhan yang sangat penting dalam penyerbukan sehingga dapat mempertahankan kelangsungan hidupnya, dan selain itu angin dapat membantu dalam penyebaran organisme.

Adanya angin juga akan mengatur suhu udara, kelembaban udara, terjadinya hujan seperti apa yang ada pada firman Allah yang artinya :

"Allah, Dialah yang mengirim angin, lalu angin itu menggerakan awan dan Allah membentangkannya di langit menurut yang dikehendakinya, dan menjadikannya bergumpal-gumpal; lalu kamu lihat hujan keluar dari celahcelahnya, maka apabila hujan itu turun mengenai hamba- 
hambaNya yang dilcehendakiNya tiba-tiba mereka menjadi gembira". QS. Ar-Rum (301): ayat 48

Cahaya, merupakan sumber energi bagi kehidupan di bumi, dengan proses fotosintesis yang dilakukan oleh tumbuhan maka cahaya matahari ini akan diubah menjadi energi yang tersimpan dalam senyawa kimia. Senyawa kimia hasil fotosintesis (karbohidrat) inilah yang nanti dijadikan sebagai sumber energi dan makanan bagi organisme hidup. Apalah yang akan terjadi bila matahari tidak lagi memancarkan cahaya? Tentunya akan terjadi malapetaka yang sangat hebat di permukaan bumi ini, maka perlu kita renungkan firman Allah SWT dalam al- Qur'an surat at-Takwir ayat 1 yang artinya :

"Apabila matahari telah digulung ( hilang cahayanya)". QS. At-Taqwir (81): ayat 1

Dalam firman Allah dijelaskan begitu pentingnya matahari bagi kehidupan, yang artinya :

"Dan Kami jadikan pelita yang amat terang (matahari)". QS. anNaba' (8): ayat 13, "Dan Kami( Allah) telah menjadikan untukmu di bumi keperluan-keperluan hidup, dan (kami menciptakan pula) makhluk yang kamu sekali-kali bukan, pemberi rezeki." QS. al-Hijr (15): ayat 2.

Sedangkan lingkungan biotik, secara garis besar meliputi mikroorganisme, tumbuhan, hewan dan manusia. Mikroorganisme merupakan jasad mahluk kecil yang berperan penting sebagai jembatan hubungan antara lingkungan biotik dengan abiotik. Keanekaragaman makhluk hidup yang ada di bumi ini, sesuai dengan firman Allah yang artinya :

"Dan tidak ada sesuatupun melainkan pada sisi Kami-lah khazanahnya, dan Kami- tidak menurunkannya melainkan dengan ukuran yang tertentu". QS. al-Hijr (15): ayat 21

Tumbuhan, merupakan makhluk yang menyediakan sumber makanan dan oksigen bagi makhluk hidup yang lain misalnya manusia, hewan maupun mikroorganisme karena kemampuannya bisa melakukan fotosintesis. Firman Allah dalam al-Qu'ran yang artinya :

"Dan Kami turunkan air yang banyak tercurah. Supaya Kami tumbuhkan dengan air itu bijibijian dan tumbuh-tumbuhan, dan kebun-kebun yang lebat

". QS an-Naba' (78): ayat 14-16. 
Adanya interaksi yang kompleks antara organisme hidup (biotik) dan abiotik dengan lingkungannya menunjukkan bahwa di alam ini antara makhluk hidup (biotik) dengan benda mati (abiotik) tidak bisa berdiri sendiri tetapi keberadaannya saling mendukung satu sama lain. Organisme hidup tidak bisa hidup tanpa adanya faktor-faktor abiotik yang ada disekitarnya, begitu juga antara organisme satu dengan organisme yang lain juga saling membutuhkan: misalnya tumbuhan tidak bisa hidup tanpa air dan tanah, hewan dan manusia tidak bisa hidup tanpa ada tumbuhan, tumbuhan tidak bisa hidup tanpa jasa mikroba sebagai pengurai bahan organik. Sehingga kalau dicermati, ternyata di dalam ekosistem yang normal akan selalu ditemukan kaidah-kaidah yang akan mengatur keseimbangan ekosistem yang ada. Di dalam ekosistem, misalnya hahwa di suatu ekosistem itu secara alamiah (homeostatis) akan terkendali, karena di dalamnya akan terjadi interaksi antara seluruh unsur-unsur lingkungan yang saling mempengaruhi dan bersifat timbal balik, interaksi tersebut terjadi antara komponen biotik dengan komponen abiotik, komponen biotik dengan komponen biotik maupun komponen abiotik dengan komponen abiotik.

Kaidah ekosistem tergantung dan dapat dipengaruhi oleh faktor tempat, waktu dan masing-masing mencerminkan sifat-sifat yang khas. Kaidah-kaidah dalam ekosistem tersebut mencerminkan bahwa pada dasarnya alam ini sebetulnya dalam keadaan seimbang dan selaras, ini merupakan bukti kekusaan Allah, sesuai dengan firman Allah dalam Al-Qur'an surat al-Mulk ayat 3 yang artinya:

"Yang telah menciptakan tujuh langit berlapis-lapis. Kamu sekali-sekali tidak melihat pada ciptaan Tuhan Yang Maha Pemurah sesuatu yang tidak seimbang. Maka lihatlah berulang-ulang, adakah kamu lihat sesuatu yang tidak seimbang". QS. Al-Mulk (67): ayat 3.

Ekosistem sebetulnya merupakan sistem yang dinamis yang terdiri dari komponen-komponen abiotik dan biotik yang saling berinteraksi. Di dalam ekosistem akan selalu terjadi aliran energi melalui serangkaian rantai makanan dan siklus hara (siklus biobeokimia yang selalu dalam keadaan seimbang).

Interkasi antara komponen ekosistem yang meliputi komponen biotik dan komponen abiotik diatas merupakan sunnatullah yang perlu kita pikirkan dan kita syukuri sebagaimana firman Allah dalam al-Qur'an surat al-Hijr ayat 19 sampai ayat $21 \mathrm{di}$ atas.

Pendekatan Pembelajaran yang Bisa Dikembangkan 
Kegiatan pembelajaran IPA khususnya biologi lebih diarahkan kepada kegiatan yang mendorong siswa belajar aktif. Dalam pemilihan pendekatan pembelajaran IPA guru selalu mempertimbangkan tentang fasilitas sekolah yang ada, misalnya laboratorium serta sumber belajar lainnya. Ada beberapa pendekatan yang bisa dipertimbangkan dalam melakukan pembelajaran antara lain :1) pendekatan konsep; 2) pendekatan ketrampilan proses; 3) pendekatan pemecahan masalah; 4) pendekatan induktif dan deduktif dan 5) pendekatan lingkungan.

b. Integrasi Pendidikan Agama Islam dan PKn

Hal lain yang memungkinkan Pendidikan Agama Islam dan PKn untuk diintegrasikan adalah bahwa Pendidikan Agama Islam dan PKn sama-sama masuk dalam kategori pendidikan karakter. ${ }^{9}$ Menurut Doni Koesoema, pendidikan karakter adalah bantuan secara sosial agar individu itu dapat tumbuh dalam menghayati kebebasannya dalam hidup bersama dengan orang lain. Pendidikan karakter bertujuan membentuk setiap pribadi menjadi insan yang berkeutamaan. ${ }^{10}$ Sedikit berbeda, Yudi Latif mengartikan pendidikan karakter sebagai istilah yang memayungi sebuah proses pembelajaran yang mendukung bagi pengembangan personal, termasuk di dalamnya adalah pembelajaran penalaran (kognitif) moral, pembelajaran sosial dan emosional, pendidikan kebajikan moral dan pendidikan keterampilan hidup. ${ }^{11}$ Yudi Latif selanjutnya melihat, pendidikan karakter menggarap pelbagai aspek dari pendidikan moral, $\mathrm{PKn}$, dan pengembangan karakter. ${ }^{12}$

Pendidikan karakter dengan begitu adalah sebuah wadah bagi pembelajaran anak didik dalam mengembangkan karakter dirinya yang bersifat individual sekaligus karakter dirinya ketika berinteraksi dengan aspek-aspek sosialitas dari kemasyarakatannya. Selayaknyalah dalam pendidikan karakter juga tersedia ruang individu dan sosial, yang masingmasing mempunyai perbedaan penekanan pedagoginya. Sebagai individu, anak didik tentu mempunyai ciri khas yang membedakannya dengan yang

9 Kata "karakter" berasal dari bahasa Yunani karasso, yang berarti cetak biru, format dasar, sidik. Karakter juga dapat dipahami sebagai sesuatu yang bebas dan tidak dapat diintervensi. Lihat Doni Koesoema, Tiga Matra Pendidikan Karakter," dalam Basis, No. 07-08, Tahun ke-56, Juli-Agustus 2007, hal. 19. Dalam Oxford Advance Learner's Dictionary disebutkan bahwa karakter adalah " a person, race, atc, mental or moral nature, mental or moral qualities that make one person, race, ect, different of from others." Lihat As Hornoby, Oxford Advance Learner's Dictionary of Current English ( Oxford : Oxford University Press, 1987 ), hal. 140.

${ }^{10}$ Doni Koesoema,....Ibid.,hal.22

${ }^{11}$ Lihat Yudi Latif, Hancur Karakter, Hancur Bangsa : Urgensi Pendidikan Karakter ," dalam Basis No. 07-08, Tahun ke-56, Juli - Agustus 2007, hal. 39.

${ }^{12}$ Ibid. 
lain, baik dalam hal kemampuan kognitif atau pengalaman dan penghayatan nilai-nilai agama. Namun, dalam perbedaan-perbedaan karakter individu, mereka dikenalkan juga dengan wilayah yang lain, di mana mereka hidup dan berinteraksi sosial, yang memberikan pemahaman bahwa mereka adalah juga bagian dari anggota masyarakat sosial. Dalam hal ini, tentu saja pengembangan nilai-nilai keadaban bersama perlu ditekankan.

Secara kebersamaan, Pendidikan Agama Islam dan PKn perlu juga mempertimbangkan dua aspek tersebut (individual dan sosial). Tanpa mempertimbangkan dua aspek itu, maka anak didik hanya akan jatuh pada keterasingan (alenation), yang pada akhirnya akan menghilangkan karakter sesungguhnya dari anak didik itu sendiri. Mereka akan kehilangan jati dirinya sebagai individu dan jati dirinya sebagai bangsa. Di sinilah kemudian tawar menawar antara wilayah inklusif dan eksklusif dalam cara pandang yang lain (the others) perlu ditekankan dan dirumuskan. Dengan begitu, maka Pendidikan Agama Islam tetap akan menghasilkan pribadipribadi yang taat dalam penghayatan iman Islamnya, tetapi juga memiliki wawasan dan keterampilan etika kemajemukan sebagai bagian dari warga Bangsa Indonesia. Sebaliknya, PKn akan tetap memberikan pemahaman yang mendalam bagi peserta didik terhadap wawasan kebangsaan dengan nilai-nilai demokratis, Ham, dan masyarakat Madani, tetapi selanjutnya juga tetap meneguhkan penghayatan keimanan mereka. Dengan dorongan penghayatan religiusitasnya ini, diharapkan mereka mempunyai cara pandang yang terbuka terhadap realitas kebangsaan yang majemuk. Di sinilah kemudian urgensi integrasi Pendidikan Agama Islam dan PKn dalam pendidikan nasional dalam rangka menciptakan wawasan multikulturalisme pada anak didik.

c. Integrasi Pendidikan Agama Islam dengan Fisika

Materi PAI diberikan di sekolah umum SD, SMP, SMA dan SMK yang meliputi tujuh unsur pokok yaitu keimanan, ibadah, Al-Qur'an, Akhlak, Syariah, muamalah dan Tarikh. Pada unsur pokok keimanan antara lain terdapat materi yang berkaitan dengan sifat-sifat Allah, misalnya Allah Maha Besar, Allah Maha Pencipta, Allah Maha Kuasa, Allah Maha Perkasa dan lain sebagainya. Dalam menjelaskan sifat-sifat Allah tersebut biasanya dilengkapi dengan dalil naqli dan aqli. Misalnya tentang salah satu sifat Allah yaitu "Allah Maha Pencipta", biasanya dalil naqli yang digunakan antara lain QS. As Sajadah : ayat 4 


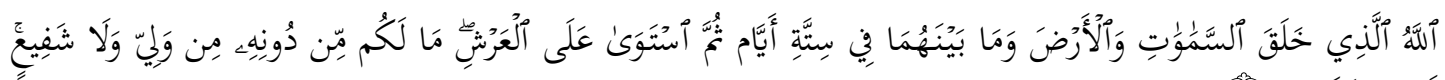

$$
\begin{aligned}
& \text { أَفَلَا تَتَذَكَرَّونَ }
\end{aligned}
$$

Artinya : Allah yang menciptakan langit dan bumi dan apa-apa yang ada diantara keduanya...." (QS. As Sajadah : 4 )

Mempelajari dalil naqli tersebut dengan cara membaca, menulis, menterjemahkan arti ayat dan menghafal ayat tersebut, barangkali tidak terlalu sulit, akan tetapi menjelaskan dan menjabarkan secara aqaliyah yang lebih rinci dan sedikit ilmiah tentang hal-hal berkaitan dengan langit, bumi dan apa-apa yang ada di antara keduanya bukanlah hal yang mudah, karena dituntut wawasan pengetahuan kealaman (natural science) yang memadai. Salah satu ilmu yang digunakan untuk menguak rahasia-rahasia alam adalah ilmu fisika, yaitu suatu ilmu pengetahuan yang mempelajari tentang tingkah laku, sifat, gerakan perubahan dan potensi alam. Untuk mudahnya penulis ambil contoh ayat di atas yang menyatakan "Allahlah yang menciptakan langit dan bumi serta apa-apa yang ada di antara keduanya". Berkaitan dengan ayat tersebut, yang beredar di sekitar matahari merupakan suatu alam yang teratur yang dimensinya sangat besar bagi ukuran manusia. Antara bumi dan matahari berjarak lebih kurang 150 juta km. Jarak ini sangat jauh bagi manusia, tapi sangat kecil bila dibandingkan dengan jarak antara matahari dengan planet yang paling jauh dalam sistem matahari.

d. Integrasi Pendidikan Agama Islam dengan Matematika

Banyak sekali contoh-contoh sederhana tentang materi Pendidikan Agama Islam dengan matematika (ilmu hitung), antara lain :

a. Zakat Maal (Harta Kekayaan)

b. Warisan

c. Ilmu matematika juga berperan dalam membantu peribadatan, seperti menentukan arah kiblat pada satu posisi di permukaan bumi, dengan perhitungan-perhitungan matematis. Di samping itu dengan rumus matematika orang dapat membuat jadwal waktu sholat di berbagai tempat. Orang juga bisa menentukan awal bulan Qomariyah, Ramadhan, Syawal, Dzulhijjah dengan mudah.

e. Integrasi Pendidikan Agama Islam dengan Kesehatan

1) Kesehatan Fisik

Salah satu factor yang sangat menentukan kesehatan fisik seseorang adalah kebersihan, dan kebersihan yang dimaksudkan di sini meliputi udara, air, 
makanan kontak langsung dan hubungan intim. Adapun contoh dari masingmasing komponen tersebut adalah sebagai berikut :

Firman Allah dalam QS. Al-Maidah : 88

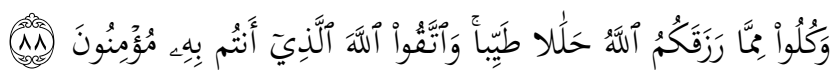

Artinya : Dan makanlah makanan yang halal lagi baik dari apa yang Allah telah rezekikan kepadamu, dan bertakwalah kepada Allah yang kamu beriman kepada-Nya.

Firman Allah dalam QS. Al-Maidah : 3

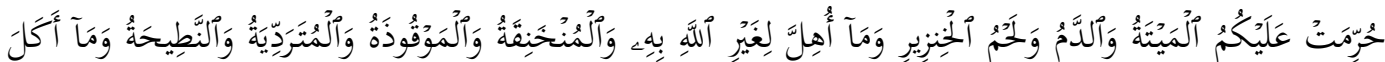

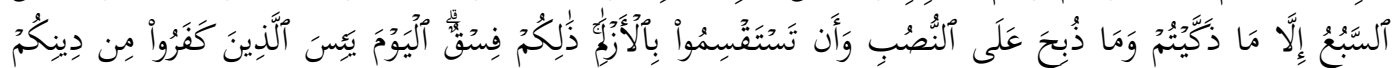

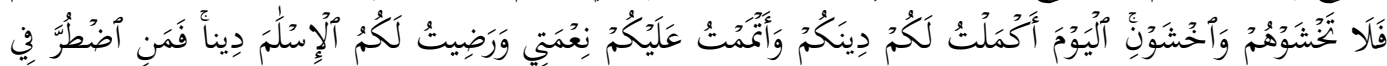

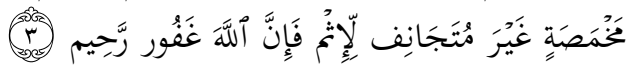

Artinya : Diharamkan bagimu (memakan) bangkai, darah, daging babi, (daging hewan) yang disembelih atas nama selain Allah, yang tercekik, yang terpukul, yang jatuh, yang ditanduk, dan diterkam binatang buas, kecuali yang sempat kamu menyembelihnya, dan (diharamkan bagimu) yang disembelih untuk berhala. dan (diharamkan juga) mengundi nasib dengan anak panah, (mengundi nasib dengan anak panah itu) adalah kefasikan. pada hari iniorang-orang kafir telah putus asa untuk (mengalahkan) agamamu, sebab itu janganlah kamu takut kepada mereka dan takutlah kepada-Ku. pada hari ini telah Kusempurnakan untuk kamu agamamu, dan telah Ku-cukupkan kepadamu nikmat-Ku, dan telah Ku-ridhai Islam itu Jadi agama bagimu. Maka barang siapa terpaksa karena kelaparan tanpa sengaja berbuat dosa, Sesungguhnya Allah Maha Pengampun lagi Maha Penyayang.

Firman Allah dalam QS. Al-Isra : 32

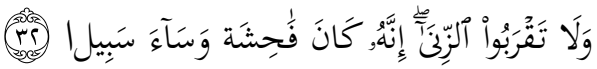

Artinya : Dan janganlah kamu mendekati zina; Sesungguhnya zina itu adalah suatu perbuatan yang keji. dan suatu jalan yang buruk.

2) Kesehatan Mental

Dalam tubuh mausia ada sekerat daging, jika dia baik maka seluruh tubuh akan baik, dan jika rusak maka seluruh tubuh akan rusak, itulah hati (qalb). Firman Allah dalam QS. Ar Radu : 28 :

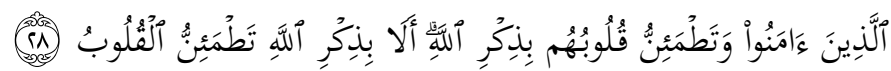


Artinya : (yaitu) orang-orang yang beriman dan hati mereka manjadi tenteram dengan mengingat Allah. Ingatlah, hanya dengan mengingati Allah-lah hati menjadi tenteram.

3) Kesehatan Sosial

Manusia diciptakan Allah sebagai mahluk individu dan sekaligus makhluk social. Hal ini menunjukkan bahwa dimanapun ia berada ia tidak akan hidup sendirian. Saling ketergantungan dan keterikatan antara yang satu dengan lainnya merupakan Sunnatullah.

Firman Allah dalam QS. Al-Hujurat:13

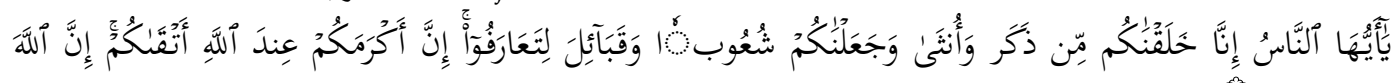
عَليمُ خَبير

Artinya : Hai manusia, Sesungguhnya Kami menciptakan kamu dari seorang lakilaki dan seorang perempuan dan menjadikan kamu berbangsa - bangsa dan bersuku-suku supaya kamu saling kenal-mengenal. Sesungguhnya orang yang paling mulia diantara kamu disisi Allah ialah orang yang paling taqwa diantara kamu. Sesungguhnya Allah Maha mengetahui lagi Maha Mengenal.

Firman Allah dalam QS. Ali Imran : 105

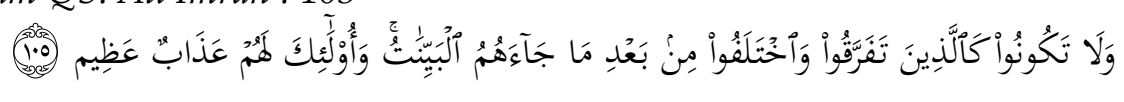

Artinya: Dan janganlah kamu menyerupai orang-orang yang bercerai-berai dan berselisih sesudah datang keterangan yang jelas kepada mereka. mereka Itulah orang-orang yang mendapat siksa yang berat,

Firman Allah dalam QS. Al-Maidah : 2

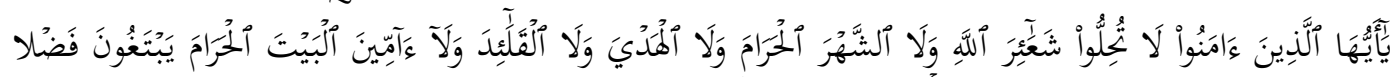

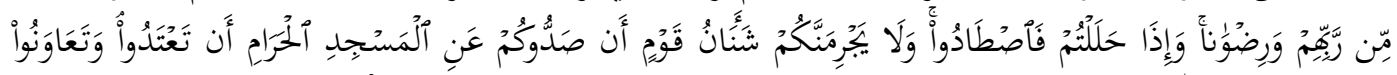

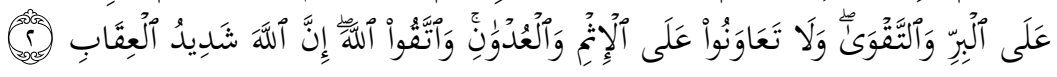

Artinya : Hai orang-orang yang beriman, janganlah kamu melanggar syi'ar-syi'ar Allah, dan jangan melanggar kehormatan bulan-bulan haram, jangan (mengganggu) binatang-binatang had-ya, dan binatang-binatang qalaaid, dan jangan (pula) mengganggu orang-orang yang mengunjungi Baitullah sedang mereka mencari kurnia dan keredhaan dari Tuhannya dan apabila kamu telah menyelesaikan ibadah haji, Maka bolehlah berburu. dan janganlah sekali-kali kebencian(mu) kepada sesuatu kaum karena mereka menghalang-halangi kamu dari Masjidilharam, 
mendorongmu berbuat aniaya (kepada mereka). dan tolongmenolonglah kamu dalam (mengerjakan) kebajikan dan takwa, dan jangan tolong-menolong dalam berbuat dosa dan pelanggaran. dan bertakwalah kamu kepada Allah, Sesungguhnya Allah Amat berat siksa-Nya.

\section{PENUTUP}

1. Pendidikan integratif lebih bersifat non paradigmatif, tapi lebih bersifat teknis.

2. Optimalisasi Pendidikan Agama. Perluasan tanggung jawab pembinaan keimanan dan ketakwaan yang selama ini berada di pundak guru agama, kini harus menjadi tugas semua guru dan komponen sekolah lainnya. Tanggung jawab ini bukan berarti bahwa guru-guru lain mengajarkan keimanan dan ketakwaan dalam format mata ajar, namun para guru di luar mata ajar agama harus mendukung terciptanya pembelajaran yang menjadikan nilai keimanan dan ketakwaan sebagai salah satu komponen, di samping bidang substansi mata ajar dan kedalaman bidang keilmuan. Langkah ini dilakukan berdasarkan prinsip bahwa dalam setiap mata ajar harus memuat tiga unsur secara terpadu, yaitu substansi mata ajar yang bersangkutan, keilmuan dan nilai (value). Dalam kerangka inilah setiap mata ajar harus memiliki nilai-nilai yang mendukung pembelajaran karakter (akhlak/moral).

3. Integrasi Imtak dan Iptek. Cara ini dilakukan dengan menganalisis pokok bahasan/sub pokok bahasan dengan mempertanyakan apakah pokok bahasan/sub pokok bahasan ada keterkaitan antara materi bahasan tersebut dengan keimanan dan ketakwaan.

4. Penciptaan situasi yang kondusif bagi pembinaan Imtak. Penciptaan situasi yang kondusif ini dimulai dengan adanya kebijakan sekolah yang mendukung dan memfasilitasi kegiatan-kegiatan keagamaan yang memungkinkan bisa meningkatkan keimanan dan ketakwaan para siswa.

5. Kerja sama antara sekolah dengan orang tua/lingkungan masyarakat.

6. Adanya buku pintar sebagai pedoman bagi guru mata pelajaran. 
FITRAH Vol. 02 No. 1 Januari-Juni 2016

\section{DAFTAR PUSTAKA}

Undang-Undang Sistem Pendidikan Nasional Nomor 20 tahun 2002, Bab II, Pasal 3, Bandung : Focus Media, 2003

Rosman Yunus dkk, Suplemen Biologi Untuk Peningkatan IMTAQ SiswaSLTA,2003,Depdiknas Dikdasmen Bag. Pro peningkatanwawasan keagamaan Guru, Jakarta : Depdiknas, 2003

Muhaimin, Paradigma Pendidikan Islam, Jakarta : 2001

Mochtar Buchori, Posisi dan Fungsi PAI dalam Kurikulum Perguruan Tinggi Umum, Jakarta :1992

Abudin Nata, Perspektif Islam Tentang Strategi Pembelajaran, Jakarta : 2007

Nana Syaodih S., Pengembangan Kurikulum, Jakarta : 2001

John Wiles \& Joseph Bondi, Curriculum Development, Jakarta : Raja Grafindo, 2007

Kadir Djaelani, Pendidikan Agama Islam dengan Mata Pelajaran Umum,t.t

Soedjatmoko, Dimensi Manusia Dalam Pembelajaran, Jakarta : LP3S, 2007

Al-Faruqi, Tauhid, Its Implication For Thought And Life, Tample University : The International Institute Of Islamic Thought : 1982 